\title{
Macroeconomic Impact of HIV/AIDS in Nigeria: Error Correction Modelling Approach
}

\author{
Rasaki Stephen Dauda (Ph.D) \\ Department of Economics and Business Studies \\ Redeemer's University, Osun State, Nigeria \\ Olanrewaju Olaniyan (Ph.D) \\ Department of Economics \\ University of Ibadan, Ibadan, Nigeria
}

\begin{abstract}
Human Immunodeficiency Virus/Acquired Immune Deficiency Syndrome (HIV/AIDS) constitutes a heavy and severe burden on the population health status and the economies of the affected countries. Nigeria's HIV/AIDS epidemic is generalized, with the country having the second highest burden of the disease in the world after South Africa. This study employed the Error Correction Modeling (ECM) approach to determine how HIV/AIDS affects the growth of the economy of Nigeria, using time series data covering the period 1980-2010. The findings showed that HIV/AIDS has a negative and significant effect on the growth of the economy of Nigeria. The coefficients of HIV incidence and its lag stood significantly at $\mathbf{- 0 . 5 7}$ and $\mathbf{- 0 . 6 3}$ respectively. The ECM variable was rightly signed, showing a negative and statistically significant coefficient of 0.19 , an indication of a $19 \%$ speed of convergence to equilibrium in the long run. The adjusted R-Squared of 81\% suggests that the regressors explained a high proportion of variation in economic growth. The findings of the study imply that HIV/AIDS is capable of reducing economic growth in Nigeria. Therefore, its spread should be properly checked.
\end{abstract}

Keywords: HIV/AIDS, Economic Growth, Error Correction Model, Nigeria

\section{INTRODUCTION}

Determination of what burden HIV/AIDS poses on the economies of nations is very critical for policy direction not only at combating the disease but also to ascertain its impact on the economic growth of the hardest hit countries. A good number of the societies affected by the epidemic incidentally are poor economies in Africa, which are already overburdened with conflicts and very low standard of living. HIV/AIDS does not only militate against growth and development of nations' economies but also keeps countries under perpetual poverty. Since the early 1980s when the first cases of the pandemic were reported in the United States (see Centers for Disease and Control Prevention (2001), its cases have continued to increase, thereby plaguing the economies of affected countries. Chakraborty, Papageorgiou \& PerezSebastian (2010) noted that the economic cost of HIV/AIDS is felt directly through premature death of infected person, decline in quality of life, low savings and productivity due to increased mortality and morbidity, and decline in the level of productivity. Available information on the states of the disease suggests that the sub-Saharan Africa (SSA) continues to bear the major brunt of the epidemic. For instance UNAIDS \& WHO (2009) and UNAIDS (2010) in their reports revealed that 25 million persons in the SSA were living with HIV/AIDS in 2009. This is about $75 \%$ of the global number while the prevalence in the region stands at $5 \%$. UNAIDS (2015a) reported that out of the 36.9 million people living with HIV/AIDS as at 
the end of 2014, approximately 25.8 million (about 70\%) of them are in SSA, out of which $80 \%$ are in 20 countries with Nigeria inclusive.

This study examined the effect of HIV/AIDS pandemic on the economic growth of Nigeria, using the Error Correction Modeling (ECM) approach. Nigeria accounts for the second largest number of HIV/AIDS infected persons globally after South Africa (see National Agency for the Control of AIDS, NACA, 2014). The number of people living with the disease in the country stood at 3.3 million, 3.1 million and 3.23 million in 2009, 2010 and 2013 respectively (see UNGASS, 2010; and NACA, 2012 \& 2014). The disease has entered a generalized epidemic status in Nigeria with prevalence being highest in the South-South geopolitical region of the country. The general prevalence in the country was 4.6\%, 4.1\% and 3.4\% in 2008, 2011 and 2013 respectively. Most macroeconomic studies on HIV/AIDS employed HIV prevalence; whereas, this paper used HIV incidence, which shows the current state of the epidemic. Moreover, macroeconomic studies on HIV/AIDS in Nigeria are scarce. Literature search produced only three, Abdulsalam (2010), Dauda (2012) and Azuh, Osabuohien, Nwaubani, \& Ugwuanyi (2014). Abdulsalam (2010) used simulation and Computable General Equilibrium (CGE) modeling approach to examine the impact of the disease on different sectors in the Nigerian economy while Dauda (2012) employed the Ordinary Least Squares (OLS) estimation technique to investigate how the disease affects the economy of the country. Azuh, Osabuohien, Nwaubani, \& Ugwuanyi (2014) however, focused on the cost implication of HIV/AIDS on economic development in Nigeria. Asides these three works, it is observed that most studies on economic implication of HIV/AIDS in the country are micro level, using primary or survey data (see Hilhorst, Liere \& Koning, 2006; Mahal, Canning, Odumosu, \& Okonkwo, 2008; Adeoti \& Adeoti, 2008 and Ugwu, 2009; and Iya, Purokayo \& Gabdo, 2012). The present paper analyzed the economic burden of HIV/AIDS in Nigeria with specific focus on its implication for economic growth, using the ECM approach. The remainder of the study is structured as follows: section two provides background information on economic growth and the state of HIV/AIDS in Nigeria while section three focuses on review of related literature. Section four presents the methodology employed in the paper. The fifth section shows empirical analysis and results while section six concludes and gives policy implications of the study.

\section{BACKGROUND}

Nigeria, an oil-rich country derives a greater proportion of her earnings from this sector, which has continued to impart positively on the growth of the country's GDP over the years until recently when oil price crashed in the international market. Moreover, the presence of communicable diseases is capable of posing challenges to her economic performance, particularly as the nation seeks to diversify her economic base. Information presented in Table 1 below revealed that the country recorded an average of $2.85 \%$ growth in her GDP for the period 1961-1969. This increased to about 7.00\% within 1970-1979. The period 1980-1989 witnessed a degeneration in the growth of the nation's economy when an average of $-1.42 \%$ was recorded. This nevertheless, may not be unconnected with the oil glut experienced by the country during this time. By 1990-1999, the economy bounced back posting a $2.63 \%$ growth. This rose appreciably to $8.93 \%$ during the $2000-2009$ period before declining to $5.74 \%$ in 2010-2014, despite the rebasing of her GDP. This notwithstanding, it is apparent that the nation's economy appears to be on a good footing. However, the economy would have performed better without the burden of communicable diseases such as HIV/AIDS. 
Table 1: Average Growth Rate of Nigeria's GDP (1961-2014)

\begin{tabular}{|c|c|}
\hline Year & GDP Growth (\%) \\
\hline $1961-$ & 2.85 \\
1969 & 7.00 \\
\hline $1970-$ & \\
\hline 1979 & -1.42 \\
\hline $1980-$ & \\
\hline 1989 & 2.63 \\
\hline $1990-$ & \\
\hline $2000-$ & 8.93 \\
\hline 2009 & \\
\hline $2010-$ & \\
\hline 2014 & \\
\hline
\end{tabular}

\section{Source: Authors' Computation from World Bank (2015). World Development Indicators}

\section{Status of HIV/AIDS in Nigeria}

Nigeria carries the second heaviest burden of HIV/AIDS in Africa going by the number of persons living with the pandemic, its incidence, prevalence, new infections and number of AIDS-related deaths (NACA, 2012; NACA, 2014, and UNAIDS, 2015a). The disease is among the leading causes of morbidity and mortality in the country. According to NACA (2012), HIV prevalence in Nigeria was $1.8 \%$ in 1991. It rose to 3.8\% and 4.5\% in 1993 and 1996 respectively before it declined marginally to $5.4 \%$ in 1999. A peep into Table 2 showed evidently that prevalence of HIV in Nigeria has maintained a steady decline over the years, except for a slight increase witnessed in 2008. In 2001, about 5.8\% prevalence was recorded. This however reduced to $4.4 \%$ in 2005 before it increased to $4.6 \%$ in 2008 . It reduced to $4.1 \%$ and 3.4\% in 2011 and 2013 respectively. Although prevalence of the virus in Nigeria appears lower than what obtains in some East and Southern African countries, the figure still stands above the 1\% prevalence level threshold that constitutes a generalized epidemic as proposed by World Bank (1997).

The number of people living with HIV/AIDS (PLWHA) in Nigeria continues to increase. In 2001, around 2.5 million people were living with the disease. This number however, rose to 3.0 million and 3.46 million in 2005 and 2011 respectively before a slight decline to 3.4 million in 2013. Moreover, the number of deaths occasioned by AIDS has been in its thousands. From 140,000 in 2001 to 180,000 in 2005 and later to 217,148 and 210,031 in 2011 and 2013 in that order. New infections have also continued to be in their thousands. In 2001, around 330 
thousand people got infected by the virus in Nigeria. This later rose to 336,379 and 388,864 in 2008 and 2011 respectively before it fell to 220,394 in 2013. The forgone facts underscore why the burden of the pandemic appears high in the country.

\begin{tabular}{|c|c|c|c|c|c|}
\hline & 2001 & 2005 & 2008 & 2011 & 2013 \\
\hline National Median HIV Prevalence (\%) & 5.8 & 4.4 & $4.6 \%$ & 4.1 & 3.4 \\
\hline Estimated Number of PLWHIV (million) & 2.50 & 3.00 & 2.98 & 3.46 & 3.40 \\
\hline Annual AIDS deaths & 140,000 & 180,000 & 192,000 & 217,148 & 210,031 \\
\hline New HIV infection & 330,000 & 310,000 & 336,379 & 388,864 & 220,394 \\
\hline
\end{tabular}

HIV prevalence in Nigeria defers among different Geo-political zones and states. As indicated in Figure 1 below, the South-South and the North-Central zones recorded the highest prevalence in 2008 and 2010while the North-West and South-West Zones recorded the least.

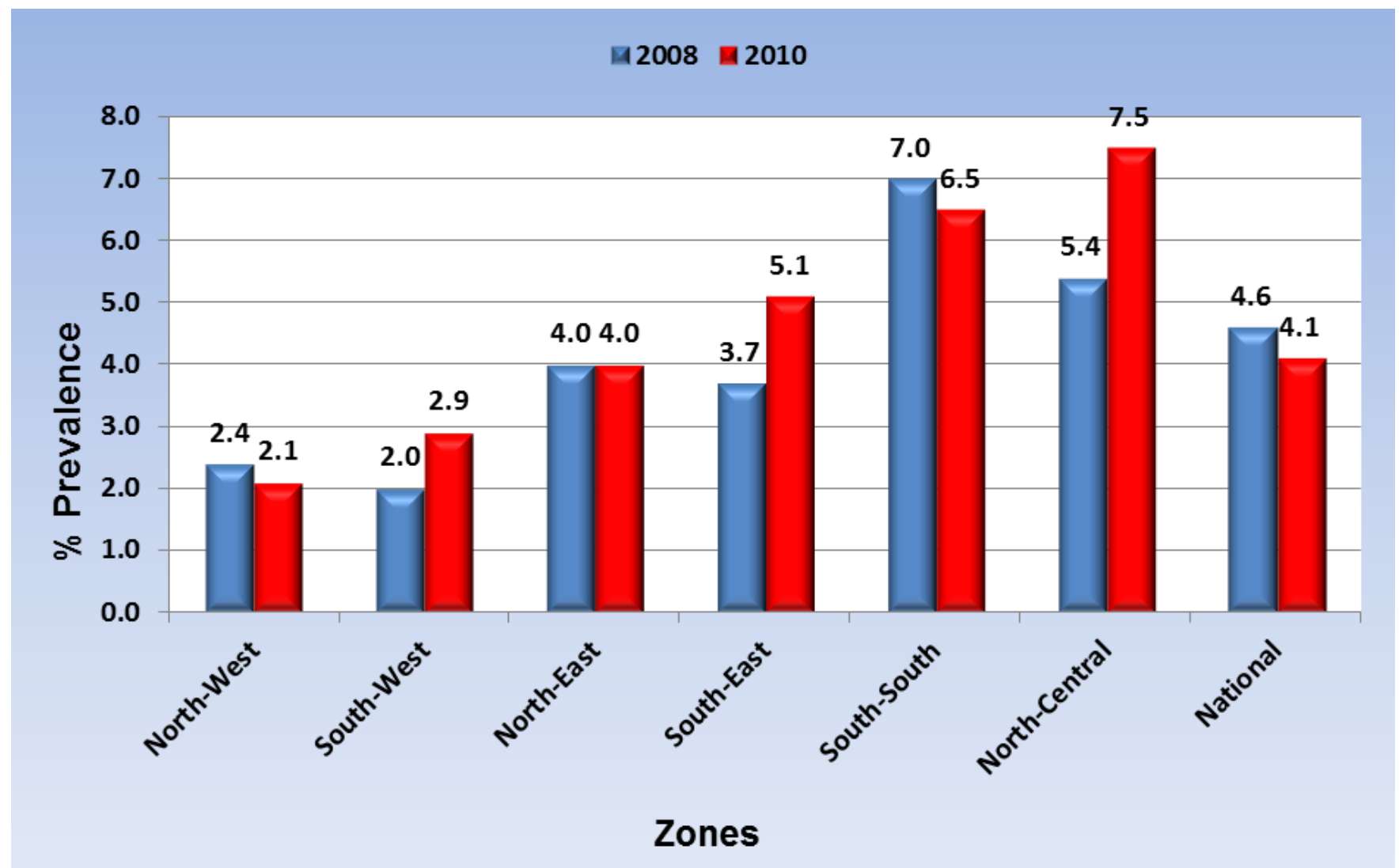

Source: NACA (2012) Global AIDS response country progress report on Nigeria. Figure 1: HIV/AIDS Prevalence by Geo-political Zones in Nigeria for 2008 and 2010.

A cursory look at the figure above shows HIV prevalence being highest in the North Central zone in 2010; put at 7.5\%, followed by the South-South with $6.5 \%$. The least prevalence in the same year was recorded in the South-West zone. North East had 4.0\% in both 2008 and 2010. Moreover, while the figure has declined in some geopolitical zones, such as the North-West and South-South, the same cannot be said of others. The South-West, which had $2.0 \%$ in 2008 recorded 2.9\% in 2010. Similarly, prevalence in the South-East zone rose from 3.7\% in 2008 to 
$5.1 \%$ in 2010. North-Central had the worst prevalence of the virus in 2010. The zone recorded a sharp increase in the figure from 5.4 in 2008 to $7.5 \%$ in 2010.

With respect to the 36 states and the Federal Capital Territory (FCT) of the country, it is observed that prevalence ranges between $15.2 \%$ in Rivers State and $0.2 \%$ in Ekiti state. Data presented by NACA on its official website showed the five states with the highest prevalence as Rivers (15.2\%), Taraba (10.5\%), Kaduna (9.2\%), Nasarawa (8.1\%) and FCT (7.5\%). States with prevalence below 1\% include: Ekiti (0.2\%), Zamfara (0.4\%), Bauchi (0.6\%), Ogun (0.6\%), Delta (0.7\%), Kasina (0.7\%), Edo (0.8\%), Kebbi (0.8\%), and Ebonyi (0.9\%).

One of the ugly pictures painted by HIV/AIDS in most affected countries is its concentration among the Productive Age Group (PAG). As shown in Table 3, an average of $0.35 \%$ and $1.62 \%$ HIV incidence and prevalence respectively were recorded among the PAG in Nigeria from 1990 to1994. By $1995-1999$ the rates have risen to $0.49 \%$ incidence and $2.86 \%$ prevalence. Incidence of the disease began to decline as from 2000-2004 period, when an average of $0.42 \%$ was recorded. However, prevalence continued to increase with 3.62\% posted for 2000-2004 time. It got peaked in 2005-2009 when an average 3.66\% was recorded among this group. Both incidence and prevalence of the pandemic stood at $0.24 \%$ and $3.36 \%$ in that order, during the 2010-2014 period. These facts further underscore the severe burden of the disease in Nigeria.

Table 3: Average HIV Incidence and Prevalence among Productive Age Group (15-49 years), 1990-2014

\begin{tabular}{|c|c|c|}
\hline Year & Incidence (\%) & Prevalence (\%) \\
\hline $1990-1994$ & 0.35 & 1.62 \\
\hline $1995-1999$ & 0.49 & 2.86 \\
\hline $2000-2004$ & 0.42 & 3.62 \\
\hline $2005-2009$ & 0.33 & 3.66 \\
\hline $2010-2014$ & 0.24 & 3.36 \\
\hline
\end{tabular}

\section{Source: UNAIDS. (2015b). How AIDS changed everything report-HIV estimates with uncertainty bounds.}

Apparently, the information provided on the status of HIV/AIDS in Nigeria attests to its heavy burden in the country and further provides justification for the present study.

On the subject of how the disease is transmitted, heterosexual intercourse appears as the major mode of transmission in Nigeria. The 2010 UNGASS country report states that about $80 \%$ to $90 \%$ of people infected with the virus in Nigeria got infected through heterosexual intercourse. However, NACA (2011) has pointed out that a large number of infections actually occur among people who do not engage in high risk sex.

\section{THE LITERATURE}

The existence of communicable diseases such as HIV/AIDS in any economy poses serious challenges. At the levels of households and firms, HIV/AIDS has been observed to have contributed to a surge in mortality and morbidity, increased medical expenses, frequent absentees at work and school, reduced households and firms incomes, increased loss of labour hour at work and on farm as well as school dropout rate among the children of infected families (Bollinger, Stover and Nwaorgu, 1999; United Nations, 2004). As the risks of morbidity, disability, impairment, illness, injury and mortality associated with the pandemic increase, the macroeconomic performances of affected countries are hampered. 
A number of literatures on macroeconomic impact of HIV/AIDS globally have emerged. However, not many of them focus on other part of the world apart from the Southern and East African countries where the prevalence of the disease appears high. Some of these studies report negative and statistically significant effect of HIV/AIDS on macroeconomic outcomes, particularly economic growth. Prominent among them are: Over (1992), Kambou, Devarajan \& Over (1992), Cuddington (1993), McDonald \& Roberts (2006), and Gardner \& Lee (2010). While the works of Over (1992), McDonald \& Roberts (2006), and Gardner \& Lee (2010) are cross-country, the others are country-specific. However, all the studies found that HIV/AIDS had contributed to decline in either GDP or per capita GDP growth.

Contrary to the findings of the above studies, Bloom \& Mahal (1997), Clark \& Vencatachellum (2003), and Cuesta (2010) reported that HIV/AIDS did not pose any significant challenge to economic growth and development.

\section{Empirical Evidence of Economic Impact of HIV/AIDS in Nigeria}

Although more empirical researches are being undertaken to determine the impact of HIV/AIDS on macroeconomic outcomes, not many of them are found in Nigeria. Most of the existing works capturing economic implication of HIV/AIDS in the country are either firm level or household level studies, which in most cases employ survey data.

For instance, Hilhorst, Liere \& Koning (2006), analyzed how AIDS has affected rural livelihoods in Benue State, Nigeria. In this area, HIV prevalence was about $9.3 \%$ at the time of the study. The authors focus on cases of chronic illness and deaths among adults who fall within the age group 15 - 49 years. The study employed data collected by the Benue State Agricultural and Rural Development Authority (BNARDA) in 2003. The findings indicated that adult morbidity and mortality rates caused by HIV infection were on the increase and income, productivity, investments and savings were negatively affected because of increased expenditures and time spent on care, funerals and mourning. Although this study may not be representative of how the disease affects rural livelihoods in Nigeria, it may not be far from what obtains in other communities within the country suffering from the scourge of HIV/AIDS.

In the same vein, Adeoti \& Adeoti (2008) examined the effect of the health status of farm households on cropping patterns, incomes and technical efficiencies in the same Benue State using data on 55 HIV/AIDS and related sicknesses infected households and 100 non-infected households. It was reported that HIV/AIDS brought about a significant decline in farm size and the variety of crops cultivated. The result further showed that average gross revenue, average gross margin and profit on farms cultivated by non-HIV infected farmers were higher than those of farms cultivated by persons infected by the disease. These findings speak volume of the economic impact of HIV/AIDS in Nigeria where a good number of the populace engaged in agriculture.

In a related study conducted by Ugwu (2009) on socio-economic effect of HIV/AIDS on farm women in Enugu State, Nigeria where about $60 \%$ of the food consumed are produced by women, it was discovered that HIV/AIDS has negative and significant impact on the farm women and their households. The feminine agricultural labour supply was observed to have reduced due to HIV/AIDS, household income declined and agricultural production also decreased. These further increased family burden and led to loss of family assets and right of the women according to the author. 
Mahal, Canning, Odumosu \& Okonkwo (2008) studied the effect of HIV/AIDS on individuals' healthcare utilization and spending in the Oyo and Plateau states of Nigeria, employing a 2004 random survey data consisting of over 6400 individuals, which were compared with a sample of 482 individuals living with HIV/AIDS. Their findings indicated that the disease has brought about significant surge in morbidity, healthcare utilization, public health facility use and decline in work time and family time devoted to care-giving. Specifically, about $56 \%$ of the affected households' annual income per capita was lost.

Furthermore, a recent study conducted by Iya, Purokayo \& Gabdo (2012) focused on the impact of HIV/AIDS on production and income among rural households in Adamawa State of Nigeria. About 120 HIV/AIDS infected persons were interviewed, and the data analyzed using descriptive logistic regression techniques of analysis. The results revealed that HIV/AIDS has negative effect on household's productivity, income, saving and capital formation.

Although all the studies reviewed above are micro in nature, their findings suggest that the HIV/AIDS disease has negative effect on economic outcomes at the micro level in Nigeria. Since the aggregation of micro variables makes up macro, it can be said that HIV/AIDS epidemic could be detrimental to macroeconomic activities in the country.

Asides the micro level studies reviewed above, literature search produced about three macroeconomic studies conducted in Nigeria. These are: Abdulsalam (2010), Dauda (2012), and Azuh, Osabuohien, Nwaubani, \& Ugwuanyi (2014). The findings of the three studies confirmed the negative influence of HIV/AIDS on macroeconomic variables in the country.

Abdulsalam (2010) investigated the potential impact of HIV/AIDS on some key sectors in the Nigerian economy over the period 1980-2000. The author developed macro-econometric model in which HIV prevalence was incorporated. The results show that the prevalence of HIV in Nigeria has the propensity to reduce output in the agriculture and manufacturing sectors, has little or a positive influence on output in the oil and gas sector while increased government spending on HIV treatment and prevention would increase output across all industries and reduce capital expenditures as well as capital formation. The few observations about this study is that the period of its focus neglects the vital aspect of the disease in which prevalence is observed to be high. From 2001 till date, prevalence has been observed to be high, particularly from 2001 to 2010 . Secondly prevalence data could be overestimated due to selection bias, and moreover, it does not measure new infections at a particular time rather it considers all individuals infected by the pandemic.

Dauda (2012) analyzed how HIV/AIDS affects the performance of the Nigerian economy over the period 1990-2010. The author specified two models, each using different measure of HIV/AIDS. In the first model, prevalence of HIV was used while number of people living with HIV/AIDS in Nigeria was employed in the second model. The ordinary least squares (OLS) estimating technique was adopted for analysis. Over all, it was discovered that HIV/AIDS has negative impact on the performance of the Nigerian economy. However, the coefficient of HIV prevalence in the first model was not significant while number of people living with the disease in the second model reduced economic growth marginally in the country, given the probability value of 0.053 . It is obvious from the study that the data point of 1990-2010 (21 years) could have influenced the insignificance and marginal significance of the results. It is possible to have violated the normality assumption underlying the linear regression model.

Finally, Azuh, Osabuohien, Nwaubani, \& Ugwuanyi (2014) studied the cost implications of HIV/AIDs on economic development in Nigeria, with focus on prevalence of the disease. The 
authors claimed that HIV/AIDS exerts "serious negative influences on the economic growth of Nigeria." Some reservations with this study is that whereas, the paper was supposed to consider cost implication of the disease on economic development, it however reported negative influence of the pandemic on growth. Furthermore, there was no basis for the findings reported by the authors because the only analysis carried out was graphical presentation of cases of HIV/AIDS over the period 1996-2005, per capita GDP over 1996-2007, and public health expenditure spanning 1996-2007. There was nothing to suggest analysis of causal relationship between HIV/AIDS and the explanatory variables. In addition, the authors further reported that "HIV/AIDS has very serious impact on the epidemiological and demographic profiles of the country as well as on health delivery system and manpower development." No analysis was carried out to have arrived at this result. Therefore, the policy recommendations by the authors suggesting "prevention of new infections, cost reduction of treatments for patients, positive adjustments of patients to employment environment and development of activities like psycho-educational programme to motivate and foster HIV/AIDS prevention and management behaviours among the Nigeria populace especially the youth", did not emerge from the study.

\section{METHODOLOGY}

This study dwelt on basic neoclassical growth framework. However, the version employed in this paper follows from Aghion \& Howitt (2007).

Given a Cobb Douglas Production function of the type:

$$
Y=A K^{\alpha} L^{1-\alpha}
$$

Where:

$Y=$ output level in the economy,

$K=$ stock of physical capital in the economy,

$L=$ stock of labour in the economy,

$A=$ Productivity parameter,

$\alpha=$ parameter of the function showing the share of income accruing to the stock of capital, and

$(1-\alpha)=$ the share of income accruing to the stock of labour in the economy.

Subjecting equation (1) to the assumption of constant returns to scale and dividing by $L$ gives the intensive form of the equation as

$$
y=A k^{\alpha}
$$

Where $y=Y / L$ and $y=K / L$ and signify output per labour and capital stock per labour respectively.

It is clear from equation (2) that there is a direct relationship between the level of output and productivity parameter, A; as well as level of capital stock in the economy. $B$ separates advancement in technology from the accumulation of capital and it "tells us not just how productive labour is, but how productively the economy uses all the factors of production" (Aghion \& Howitt, 2007, p. 81).

The rate at which the economy grows is then given as $g_{y}$

Based on equation (2)

$$
g_{y}=g_{k}
$$

Where

$$
g_{y}=g_{Y}=\frac{\Delta Y}{Y}
$$

and

$$
g_{k}=g_{K}=\frac{\Delta K}{K}
$$


Which implies from equation (2) that

$$
g_{y}=\frac{\Delta Y}{Y}=\frac{\Delta K}{K}
$$

Therefore,

$$
g_{y}=\frac{\Delta B}{B}+\alpha\left(\frac{\Delta K}{K}\right)
$$

Equation (7) implies that the summation of the two components, $\frac{\Delta B}{B}$ and $\alpha\left(\frac{\Delta K}{K}\right)$ determines the rate at which the economy grows.

However, there are other determinants of growth such as human capital (which can be decomposed into education variable and health variable), foreign direct investment, trade openness, epidemiological environment among others. A disease such as HIV/AIDS can be captured by the epidemiological environment, and this normally imparts negatively on economic growth, either directly or through human capital variable.

\section{Empirical Model}

The empirical model estimated in this study is given as

$$
\ln R G D P=\alpha_{0}+\alpha_{1} \ln L B F+\alpha_{2} \ln F C F+\alpha_{3} \ln E D U+\alpha_{4} \ln H E T+\alpha_{5} \ln L E P+\alpha_{6} T O P+\alpha_{7} T B C+\alpha_{8} H I V+\varepsilon
$$

Equation (8) is a long-run model. However, the study employed the ECM modeling approach, which is a dynamic short-run model.

Error Correction Model (ECM)

Basically, the structure of ECM can be shown as:

$$
\Delta Y_{t}=\alpha_{0}+\alpha_{1} \Delta X_{t-1}+\lambda E C M_{t-1}+\varepsilon_{t}
$$

Where:

$Y$ is the explained variable and $X$ a vector of explanatory variables. $\Delta$ is the difference operator while ECM stands for the error correction component of the model. This is used to measure the speed of adjustment. It actually corrects the speed of deviation from long-run equilibrium.

Based on the above, the empirical ECM is given as

$$
\begin{aligned}
& \Delta \ln R G D P_{t}=\alpha_{0}+\sum_{i=1}^{2} \alpha_{1} \Delta \ln R G D P_{t-i}+\sum_{i=1}^{2} \alpha_{2} \Delta \ln L B F_{t-i}+\sum_{i=1}^{2} \alpha_{3} \Delta \ln F C F_{t-i}+\sum_{i=1}^{2} \alpha_{4} \Delta \ln E D U_{t-i}+ \\
& \sum_{i=1}^{2} \alpha_{5} \Delta \ln H E T_{t-i}+\sum_{i=1}^{2} \alpha_{6} \Delta \ln L E P_{t-i}+\sum_{i=1}^{2} \alpha_{7} \Delta T O P_{t-i}+\sum_{i=1}^{2} \alpha_{8} \Delta T B C_{t-i}+\sum_{i=1}^{2} \alpha_{9} \Delta H I V_{t-i}+\lambda E C M_{t-i}+\varepsilon_{t}
\end{aligned}
$$

ECM in equation (10) measures the speed at which $\ln R G D P$ returnes to equilibrium after a change in any of the explanatory variables.

$\begin{array}{lll}\epsilon & = & \text { Stochastic Disturbance Term; } \\ \alpha_{0} & = & \text { Intercept of the model; and } \\ \alpha_{1 \ldots \alpha_{8}} & = & \text { The slopes of the regression or behavioural parameters. }\end{array}$

A priori, it is expected that $\alpha_{1 \ldots} \alpha_{6}>0$ while $\alpha_{7}$ and $\alpha_{8}<0$. 


\begin{tabular}{|c|c|c|}
\hline Variables & Definition & Sources \\
\hline RGDP & $\begin{array}{c}\text { Real Gross Domestic Product per } \\
\text { capita }\end{array}$ & World Development Indicators (2012) \\
\hline LBF & Labour Force & $\begin{array}{l}\text { Central Bank of Nigeria Statistical Bulletin (2010) and } \\
\qquad(2012)\end{array}$ \\
\hline FCF & Fixed/Physical Capital & $\begin{array}{l}\text { Central Bank of Nigeria Statistical Bulletin (2010) and } \\
\qquad(2012)\end{array}$ \\
\hline EDU & Public total Education Expenditure & $\begin{array}{l}\text { Central Bank of Nigeria Statistical Bulletin (2010) and } \\
\qquad(2012)\end{array}$ \\
\hline HET & Public total Health Expenditure & $\begin{array}{l}\text { Central Bank of Nigeria Statistical Bulletin (2010) and } \\
\qquad(2012)\end{array}$ \\
\hline LEP & Life Expectancy & World Development Indicators(2012) \\
\hline TOP & Trade Openness & PENN World Table (2012) \\
\hline TBC & Incidence of Tuberculosis in Nigeria & World Development Indicators (2012) \\
\hline HIV & Incidence of HIV/AIDS in Nigeria & $\begin{array}{l}\text { UNAIDS (2010) and NACA (2012) Global AIDS response } \\
\text { country progress report }\end{array}$ \\
\hline
\end{tabular}

\section{Source: Authors' Presentation}

Asides HIV incidence data collected from UNAIDS, which cover the period 1990-2010, the remaining data for the period 1980-1989 were determined through backward projection, using the UNAIDS Estimation and Projection Package (EPP), Spectrum 4.

\section{Unit Root Test}

\section{EMPIRICAL RESULTS AND DISCUSSIONS}

In this study, the variables employed were tested for stationarity, using the Augmented Dickey Fuller (ADF) and the Phillips Peron unit root tests. The null hypothesis for this test is that a unit root exists. This implies that the variables under consideration are not stationary; if they are, there should be no unit root. The tests were conducted with a constant/intercept term and trend. The results are presented in Table 5. Apparently, two variables, real GDP per capita and trade openness refused to reject the null hypothesis of the presence of unit root. All other variables rejected the null hypothesis. However, they became stationary at first difference. The implication of these is that while only two variables were integrated of order 0 , which is I(0), all others were integrated of order 1, meaning an I(1). Incidentally, since the two variables which were stationary at level also show stationarity at first difference, a cointegration test was conducted to determine the long run relationship that exists among the variables. The results are presented in Tables 6 and 7. 
Table 5: Unit Root Tests

\begin{tabular}{|c|c|c|c|c|c|c|c|c|c|}
\hline \multirow{3}{*}{$\begin{array}{l}\text { Variabl } \\
\text { es }\end{array}$} & \multicolumn{4}{|c|}{ Augmented Dickey Fuller } & \multicolumn{4}{|c|}{ Phillips Peron } & \multirow{3}{*}{$\begin{array}{l}\text { Order of } \\
\text { Integrat } \\
\text { ion }\end{array}$} \\
\hline & \multicolumn{2}{|c|}{$\begin{array}{l}\text { Test Stat. } \\
\text { With Constant }\end{array}$} & \multicolumn{2}{|c|}{$\begin{array}{l}\text { Test Stat. } \\
\text { With Constant } \\
\text { and Trend }\end{array}$} & \multicolumn{2}{|c|}{$\begin{array}{l}\text { Test Stat. } \\
\text { With Constant }\end{array}$} & \multicolumn{2}{|c|}{$\begin{array}{l}\text { Test Stat. } \\
\text { With Constant } \\
\text { and Trend }\end{array}$} & \\
\hline & Level & FD & \begin{tabular}{|l|} 
Level \\
\end{tabular} & FD & Level & FD & Level & FD & \\
\hline $\ln R G D P$ & $\begin{array}{l}-4.691 \\
(0.001)\end{array}$ & $\begin{array}{l}- \\
36.117 \\
(0.000)\end{array}$ & $\begin{array}{l}- \\
13.532 \\
(0.000)\end{array}$ & $\begin{array}{l}- \\
38.373 \\
(0.000)\end{array}$ & $\begin{array}{l}-4.178 \\
(0.003 \\
)\end{array}$ & $\begin{array}{l}-27.180 \\
(0.000)\end{array}$ & $\begin{array}{l}-8.709 \\
(0.000)\end{array}$ & $\begin{array}{l}-32.240 \\
(0.000)\end{array}$ & $\mathrm{I}(0)$ \\
\hline HIV & $\begin{array}{l}-1.251 \\
(0.639)\end{array}$ & $\begin{array}{l}-6.003 \\
(0.000)\end{array}$ & \begin{tabular}{|l|}
-1.378 \\
$(0.847)$
\end{tabular} & $\begin{array}{l}-6.027 \\
(0.000)\end{array}$ & $\begin{array}{l}-1.227 \\
(0.650\end{array}$ & $\begin{array}{l}-5.995 \\
(0.000)\end{array}$ & $\begin{array}{l}-1.361 \\
(0.852)\end{array}$ & $\begin{array}{l}-6.030 \\
(0.000)\end{array}$ & $\mathrm{I}(1)$ \\
\hline TBC & $\begin{array}{l}-1.396 \\
(0.571 \\
)\end{array}$ & $\begin{array}{l}-5.100 \\
(0.000 \\
)\end{array}$ & $\begin{array}{l}-0.957 \\
(0.935)\end{array}$ & $\begin{array}{l}-5.243 \\
(0.001 \\
)\end{array}$ & $\begin{array}{l}-1.396 \\
(0.571\end{array}$ & $\begin{array}{l}-5.100 \\
(0.000)\end{array}$ & $\begin{array}{l}-1.019 \\
(0.926)\end{array}$ & $\begin{array}{l}-5.241 \\
(0.001)\end{array}$ & $\mathrm{I}(1)$ \\
\hline $\operatorname{lnEDU}$ & $\begin{array}{l}0.222 \\
(0.970\end{array}$ & $\begin{array}{l}-6.361 \\
(0.000)\end{array}$ & $\begin{array}{l}-3.345 \\
(0.078)\end{array}$ & $\begin{array}{l}-6.249 \\
(0.000)\end{array}$ & $\begin{array}{l}0.306 \\
(0.975 \\
)\end{array}$ & $\begin{array}{l}-6.336 \\
(0.000)\end{array}$ & $\begin{array}{l}-3.358 \\
(0.077)\end{array}$ & $\begin{array}{l}-6.226 \\
(0.000)\end{array}$ & $\mathrm{I}(1)$ \\
\hline lnHET & $\begin{array}{l}0.262 \\
(0.972 \\
)\end{array}$ & $\begin{array}{l}-8.457 \\
(0.000)\end{array}$ & $\begin{array}{l}-4.345 \\
(0.009 \\
)\end{array}$ & $\begin{array}{l}-8.461 \\
(0.000)\end{array}$ & $\begin{array}{l}0.211 \\
(0.969 \\
)\end{array}$ & $\begin{array}{l}-9.996 \\
(0.000)\end{array}$ & $\begin{array}{l}-4.317 \\
(0.010)\end{array}$ & $\begin{array}{l}-11.632 \\
(0.000)\end{array}$ & $\mathrm{I}(1)$ \\
\hline $\operatorname{lnFCF}$ & $\begin{array}{l}-2.245 \\
(0.196\end{array}$ & $\begin{array}{l}- \\
5.0596 \\
(0.000 \\
)\end{array}$ & $\begin{array}{l}-1.968 \\
(0.594)\end{array}$ & $\begin{array}{l}-5.287 \\
(0.001)\end{array}$ & $\begin{array}{l}-2.301 \\
(0.178 \\
)\end{array}$ & $\begin{array}{l}-5.058 \\
(0.000)\end{array}$ & $\begin{array}{l}-1.825 \\
(0.667)\end{array}$ & $\begin{array}{l}-6.600 \\
(0.000)\end{array}$ & $\mathrm{I}(1)$ \\
\hline $\ln L B F$ & $\begin{array}{l}-0.828 \\
(0.792)\end{array}$ & $\begin{array}{l}-9.796 \\
(0.000 \\
)\end{array}$ & $\begin{array}{l}-4.600 \\
(0.006)\end{array}$ & $\begin{array}{l}-5.164 \\
(0.002 \\
)\end{array}$ & $\begin{array}{l}0.747 \\
(0.991 \\
)\end{array}$ & $\begin{array}{l}-1.549 \\
(0.495)\end{array}$ & $\begin{array}{l}-2.632 \\
(0.270)\end{array}$ & $\begin{array}{l}-1.196 \\
(0.893)\end{array}$ & $\mathrm{I}(1)$ \\
\hline $\operatorname{lnLEP}$ & $\begin{array}{l}1.487 \\
(0.999)\end{array}$ & $\begin{array}{l}-4.122 \\
(0.004)\end{array}$ & $\begin{array}{l}-3.569 \\
(0.052)\end{array}$ & $\begin{array}{l}-5.931 \\
(0.000)\end{array}$ & $\begin{array}{l}1.946 \\
(1.00 \\
0)\end{array}$ & $\begin{array}{l}-0.852 \\
(0.789)\end{array}$ & $\begin{array}{c}0.112 \\
(0.996)\end{array}$ & $\begin{array}{l}-2.001 \\
(0.576)\end{array}$ & $\mathrm{I}(1)$ \\
\hline TOP & $\begin{array}{l}-3.913 \\
(0.006 \\
)\end{array}$ & $\begin{array}{l}-7.136 \\
(0.000)\end{array}$ & \begin{tabular}{|l|}
-3.677 \\
$(0.040)$
\end{tabular} & $\begin{array}{l}7.429 \\
(0.000)\end{array}$ & $\begin{array}{l}-3.953 \\
(0.00 \\
5)\end{array}$ & $\begin{array}{l}-7.178 \\
(0.000)\end{array}$ & $\begin{array}{l}-3.685 \\
(0.039)\end{array}$ & $\begin{array}{l}-7.504 \\
(0.000)\end{array}$ & $\mathrm{I}(0)$ \\
\hline
\end{tabular}

\section{Source: Authors' Computation}

\section{Johansen Cointegration Test}

The cointegration test conducted in this study followed the Johansen (1991) approach using two different likelihood ratio test statistics to determine the number of cointegrating equations. The test statistics are the trace and maximal eigenvalue. From the results presented in Tables 6 and 7, trace and maximal eigenvalue tests showed seven (7) cointegrating equations at the 0.05 level. The import of this is that there exists a long run relationship among the variables used in the study. 
Table 6: Unrestricted Cointegration Rank Test (Trace)

\begin{tabular}{|c|c|c|c|c||}
\hline Hypothesized & & Trace & $\mathbf{0 . 0 5}$ & \\
\hline No. of CE(s) & Eigenvalue & Statistic & Critical Value & Prob. $^{* *}$ \\
\hline None $^{*}$ & 0.997 & 521.11 & 159.53 & 0.00 \\
\hline At most 1 & 0.986 & 351.47 & 125.62 & 0.00 \\
\hline At most 2 & 0.943 & 227.62 & 95.75 & 0.00 \\
\hline At most 3 & 0.832 & 144.57 & 69.82 & 0.00 \\
\hline At most 4 & 0.758 & 92.85 & 47.86 & 0.00 \\
\hline At most 5 & 0.647 & 51.77 & 29.80 & 0.00 \\
\hline At most 6 & 0.474 & 21.59 & 15.50 & 0.01 \\
\hline At most 7 & 0.098 & 2.98 & 3.84 & 0.08 \\
\hline \multicolumn{5}{|}{ Trace test indicates 6 cointegratingeqn(s) at the 0.05 level } \\
\hline * denotes rejection of the hypothesis at the 0.05 level \\
\hline ** MacKinnon-Haug-Michelis (1999) p-values \\
\hline
\end{tabular}

Source: Authors' Computatio

Table 7: Unrestricted Cointegration Rank Test (Maximum Eigenvalue)

\begin{tabular}{|c|c|c|c|c|}
\hline Hypothesized & & Max-Eigen & 0.05 & \\
\hline No. of CE(s) & Eigenvalue & Statistic & Critical Value & Prob.** \\
\hline None $^{*}$ & 0.997 & 169.642 & 52.363 & 0.000 \\
\hline At most ${ }^{*}$ & 0.986 & 123.849 & 46.231 & 0.000 \\
\hline At most 2 & 0.943 & 83.052 & 40.078 & 0.000 \\
\hline At most 3 & 0.832 & 51.713 & 33.877 & 0.000 \\
\hline At most 4 & 0.758 & 41.080 & 27.584 & 0.001 \\
\hline At most 5 & 0.647 & 30.180 & 21.132 & 0.002 \\
\hline At most 6 & 0.474 & 18.614 & 14.265 & 0.010 \\
\hline At most 7 & 0.098 & 2.979 & 3.842 & 0.084 \\
\hline \multicolumn{4}{|c|}{ Max-eigenvalue test indicates 7 cointegrating eqn(s) at the 0.05 level } \\
\hline ** denotes rejection of the hypothesis at the 0.05 level \\
\hline
\end{tabular}

\section{Source: Authors' Computation}

Table 8: ADF and PP Unit Root Tests on the Residual Series

\begin{tabular}{|c|c|c|c|c|c|c|c|c|}
\hline Variables & \multicolumn{3}{|c|}{ Augmented Dickey Fuller } & \multicolumn{4}{c|}{ Phillips Peron } \\
\hline & \multicolumn{2}{|c|}{$\begin{array}{c}\text { Test Stat. with } \\
\text { Constant }\end{array}$} & \multicolumn{2}{c|}{$\begin{array}{c}\text { Test Stat. with } \\
\text { Constant \& Trend }\end{array}$} & \multicolumn{2}{c|}{$\begin{array}{c}\text { Test Stat. with } \\
\text { Constant }\end{array}$} & \multicolumn{2}{c|}{$\begin{array}{c}\text { Test Stat. with } \\
\text { Constant \& Trend }\end{array}$} \\
\hline & Level & FD & Level & FD & Level & FD & Level & FD \\
\hline Residual & -5.409 & -3.141 & -4.230 & -4.153 & -8.154 & -19.944 & -8.433 & -31.020 \\
& $(0.000)$ & $(0.036)$ & $(0.012)$ & $(0.017)$ & $(0.000)$ & $(0.000)$ & $(0.000)$ & $(0.000)$ \\
\hline
\end{tabular}

Source: Authors' Computation

Table 8 above shows the results of the unit root test conducted on the residual series. It is evident from the table that the residual series is stationary at level, implying an I $(0)$ series. 
Table 9: Over Parameterized Dynamic Error Correction Results

\begin{tabular}{|c|c|c|c|c|}
\hline \multicolumn{4}{|c|}{ Dependent Variable: D(InRGDP) } & \multirow[b]{2}{*}{ Prob. } \\
\hline Variable & Coefficient & Std. Error & $\begin{array}{c}\text { t- } \\
\text { Statist } \\
\text { ic } \\
\end{array}$ & \\
\hline Constant & -0.247 & 2.012 & -0.123 & 0.914 \\
\hline$\Delta(\ln (E D U))$ & 0.038 & 0.084 & 0.455 & 0.694 \\
\hline$\Delta(\ln (\operatorname{EDU}(-1)))$ & -0.023 & 0.160 & -0.141 & 0.901 \\
\hline$\Delta(\ln (\operatorname{EDU}(-2)))$ & -0.039 & 0.169 & -0.228 & 0.841 \\
\hline$\Delta(\ln (F C F))$ & -0.030 & 0.050 & -0.592 & 0.614 \\
\hline$\Delta(\operatorname{lnG}(F C F(-1)))$ & -0.060 & 0.060 & -0.998 & 0.423 \\
\hline$\Delta(\ln (F C F(-2)))$ & -0.007 & 0.028 & -0.233 & 0.837 \\
\hline$\Delta(\ln (\mathrm{HET}))$ & -0.096 & 0.080 & -1.200 & 0.353 \\
\hline$\Delta(\ln ($ HET $(-1)))$ & -0.118 & 0.083 & -1.425 & 0.290 \\
\hline$\Delta(\ln ($ HET $(-2)))$ & -0.063 & 0.056 & -1.135 & 0.374 \\
\hline$\Delta(\ln (\mathrm{LEP}))$ & -177.762 & 277.627 & -0.640 & 0.588 \\
\hline$\Delta(\ln (\operatorname{LEP}(-1)))$ & 405.954 & 560.158 & 0.725 & 0.544 \\
\hline$\Delta(\ln (\operatorname{LEP}(-2)))$ & -228.109 & 308.642 & -0.739 & 0.537 \\
\hline$\Delta(\ln (\mathrm{LBF}))$ & 52.799 & 232.673 & 0.227 & 0.842 \\
\hline$\Delta(\ln (\operatorname{LBF}(-1)))$ & -58.551 & 294.019 & -0.199 & 0.861 \\
\hline$\Delta(\ln (\mathrm{LBF}(-2)))$ & 18.7254 & 138.876 & 0.135 & 0.905 \\
\hline$\Delta($ HIV $)$ & -0.529 & 0.505 & -1.049 & 0.404 \\
\hline$\Delta(H I V(-1))$ & -0.914 & 0.986 & -0.927 & 0.452 \\
\hline$\Delta(H I V(-2))$ & 0.202 & 0.601 & 0.337 & 0.768 \\
\hline$\Delta(\mathrm{TBC})$ & -0.006 & 0.005 & -1.059 & 0.4001 \\
\hline$\Delta(\mathrm{TBC}(-1))$ & -0.011 & 0.012 & -0.922 & 0.454 \\
\hline$\Delta(\mathrm{TBC}(-2))$ & 0.004 & 0.009 & 0.398 & 0.729 \\
\hline$\Delta$ (TOP) & 0.002 & 0.003 & 0.593 & 0.614 \\
\hline$\Delta($ TOP $(-1))$ & 0.002 & 0.002 & 1.031 & 0.411 \\
\hline$\Delta(\mathrm{TOP}(-2))$ & 0.003 & 0.002 & 1.061 & 0.400 \\
\hline $\operatorname{ECM}(-1)$ & -0.075 & 0.450 & -0.168 & 0.882 \\
\hline R-squared & 0.963 & Mean dep & ent var & 0.049 \\
\hline $\begin{array}{l}\text { Adjusted R- } \\
\text { squared }\end{array}$ & 0.494 & S.D. depe & nt var & 0.051 \\
\hline S.E. of regression & 0.036 & Akaike inf & iterion & -4.581 \\
\hline Sum squared resid & 0.003 & Schwarz & erion & -3.344 \\
\hline Log likelihood & 90.128 & Hannan-Q & n criter. & -4.202 \\
\hline F-statistic & 2.053 & Durbin-W & on stat & 2.837 \\
\hline Prob(F-statistic) & 0.3798 & & & \\
\hline
\end{tabular}

Source: Authors' Computation

Table 9 is a presentation of the results of the over parameterized model employed to deal with any misspecification problem associated with the model. From this, the parsimonious model was arrived at through the elimination of variables with high probabilities. The remaining were re-run which produced the results shown in Table 10. 
Table 10: Parsimonious Error Correction Model Results

\begin{tabular}{|c|c|c|c|c|}
\hline \multicolumn{4}{|c|}{ Dependent Variable: D(LOG(RGDP)) } & \multirow[b]{2}{*}{ Prob. } \\
\hline Variable & Coefficient & Std. Error & t-Statistic & \\
\hline Constant & $0.116^{* * *}$ & 0.020 & 5.732 & 0.000 \\
\hline$\Delta(\ln (\mathrm{EDU}))$ & 0.005 & 0.023 & 0.233 & 0.820 \\
\hline$\Delta(\ln (\mathrm{FCF}))$ & -0.017 & 0.012 & -1.517 & 0.160 \\
\hline$\Delta(\operatorname{lnFCF}(-1)))$ & $-0.043^{* * *}$ & 0.011 & -4.102 & 0.002 \\
\hline$\Delta(\ln (\mathrm{HET}))$ & $-0.079 * * *$ & 0.017 & -4.759 & 0.001 \\
\hline$\Delta(\ln (\operatorname{HET}(-1)))$ & $-0.106^{* * *}$ & 0.021 & -5.167 & 0.000 \\
\hline$\Delta(\ln (\operatorname{HET}(-2)))$ & $-0.063^{* * *}$ & 0.013 & -4.789 & 0.001 \\
\hline$\Delta(\ln (\mathrm{LEP}))$ & $-237.090 * * *$ & 51.637 & -4.592 & 0.001 \\
\hline$\Delta(\ln (\operatorname{LEP}(-1)))$ & $515.463^{* * *}$ & 109.875 & 4.691 & 0.001 \\
\hline$\Delta(\ln (\operatorname{LEP}(-2)))$ & $-284.850 * * *$ & 61.370 & -4.642 & 0.001 \\
\hline$\Delta$ (HIV) & $-0.574^{* * *}$ & 0.143 & -4.010 & 0.003 \\
\hline$\Delta(\mathrm{HIV}(-1))$ & $-0.634^{* * *}$ & 0.138 & -4.589 & 0.001 \\
\hline$\Delta(\mathrm{TBC})$ & $-0.007^{* * *}$ & 0.002 & -3.603 & 0.005 \\
\hline$\Delta(\mathrm{TBC}(-1))$ & $-0.008^{* * *}$ & 0.002 & -4.427 & 0.001 \\
\hline$\Delta(\mathrm{TOP})$ & $0.002^{* * *}$ & 0.001 & 2.709 & 0.022 \\
\hline$\Delta(\mathrm{TOP}(-1))$ & $0.002^{* * *}$ & 0.001 & 2.791 & 0.019 \\
\hline$\Delta(\mathrm{TOP}(-2))$ & $0.002^{* * *}$ & 0.001 & 2.715 & 0.022 \\
\hline $\operatorname{ECM}(-1)$ & $-0.190 * * *$ & 0.051 & -3.750 & 0.004 \\
\hline R-squared & 0.931 & Mean c & & 0.049 \\
\hline Adjusted R-squared & 0.814 & S.D. d & at var & 0.051 \\
\hline S.E. of regression & 0.022 & Akaike & terion & -4.544 \\
\hline Sum squared resid & 0.005 & Schw & erion & -3.687 \\
\hline Log likelihood & 81.611 & Hannar & criter. & -4.282 \\
\hline F-statistic & 7.949 & Durbir & n stat & 2.286 \\
\hline Prob(F-statistic) & 0.001 & & & \\
\hline
\end{tabular}

Note: All the variables with the exception of HIV/AIDS incidence, incidence of tuberculosis and trade openness are in there natural $\log$ form. ${ }^{* * *},{ }^{* *}$ and $*$ denote statistical significance at $1 \%$, $5 \%$ and $10 \%$ level of significance while $\Delta$ indicates difference operator.

\section{Source: Authors' Computation}

The parsimonious error correction model results reported in Table 10 above indicate that the variable of interest, incidence of HIV/AIDS in Nigeria exerts negative and significant impact on the growth of the nation's economy. About 0.57 decline in per capita real GDP was occasioned by an increase in HIV incidence while the coefficient of its lag was -0.63 . The results conform to the a priori expectation of negative relationship between GDP per capita and HIV/AIDS incidence. Incidence of tuberculosis has negative and statistically significant effect on per capita real GDP. However, the coefficient $(-0.01)$ was low. Other variables such as education expenditure, lag of life expectancy, trade openness and its first and second lags had positive 
and statistically significant coefficients with the exception of education expenditure, which was positive but insignificant. Fixed capital and its first lag, health expenditure with its first and second lags, and current level of life expectancy with its second lag show negative sign, which contradicts the expected positive signs. The error correction variable gave the right sign of negative and statistically significant coefficient of 0.19 . The import of this is that about $19 \%$ of any incongruity in per capita real gross domestic product in the short run is adjusted in the next period of a year. This means that the speed of convergence to equilibrium in the long run is $19 \%$. The adjusted R-Squared of $81 \%$ is an indication that the variables employed in the study explained a high proportion of variation in per capita real GDP.

\section{DISCUSSION OF FINDINGS}

Three focal empirical analyses were carried out, namely stationarity tests, cointegration analysis and error correction model estimation. The stationarity/unit root tests were performed using the Augmented Dickey Fuller (ADF) and the Phillips-Peron tests. The results indicated that all the variables were stationary at the first difference except real GDP per capita and trade openness, which were stationary at level. Since these two variables were also stationary at first difference, it could be deduced that nearly all the variables were integrated of the same order. This necessitated the test of cointegration among the variables. Having done this, using the Johansen (1991) approach, it was discovered that there were seven (7) cointegrating equations, implying the presence of a long run relationship is present among the variables. This then led to the estimation of error correction model. The findings showed evidently that a negative and significant relationship exists between HIV/AIDS and per capita real GDP in Nigeria after controlling for major diseases and other variables. Quantitatively, incidence of HIV in the country led to a $0.57 \%$ reduction in the level of per capita GDP within the period under consideration. This finding appears consistent with Mahal, Canning, Odumosu \& Okonkwo (2008), Abdulsalam (2010), Dauda (2012), and Iya, Purokayo \& Gabdo (2012) who reported negative impact of HIV/AIDS on household's productivity, income, saving and capital formation. In specific term, Mahal et al (2008) reported about 56\% reduction in annual income per head among households in plateau and Oyo state of Nigeria due to the menace of HIV/AIDS. Dauda also found about 19\% marginally significant decline in output level in Nigeria due to a $100 \%$ increase in the number of people living with HIV/AIDS in the country while Abdulsalam (2010) discovered a significant negative effect of HIV/AIDS on agricultural and manufacturing output levels. In the same vein, studies in other countries also support this finding (see Over, 1992; Cuddington, 1993; Bonnel, 2000 and Gardner \& Lee, 2010).

Although very low proportion of the Nigerian labour force is engaged in the oil sector (the main source of foreign exchange earnings and the major contributor to the level of GDP), in recent times, the contribution of non-oil sector to the level of gross domestic product has continued to rise. This is not unexpected because efforts are being put in place to diversify the economy and a good hjumber of other sectors engage greater percentage of the nation's labour force. For instance, around 70\% of the nation's population live in the rural area with majority of them engaged in agriculture and other small and medium scale enterprises. This set of people could be at the mercy of the disease in the absence of policy intervention. Apparently, the findings presented in this paper, which is also consistent with other studies indicate that the HIV/AIDS disease could hamper productivity within the Nigerian economy, especially in the non-oil sector if no policy is put in place to check its spread.

Furthermore, education expenditure has positive but statistically insignificant effect on output level. Fixed capital and its lag produced counterintuitive results of negative impact on output. While the impact was not significant, the lag coefficient which was -0.04 was significant. The possible explanation for this may not be unconnected with the dwindling state of 
infrastructure in the country and the low rate of government's capital expenditure as a percentage of the GDP. Information available from Central Bank of Nigeria (2014) revealed that in 1981, the percentage of the nation's GDP earmarked for government expenditure was $6.96 \%$. This declined to $4.06 \%$ by 1985 . It reduced further to $5.09 \%$ in 1990 . As a matter of fact, since, 2000 the rate has remained a single digit, deteriorating as low as $3.57 \%$ in 2000 , $3.56 \%$ in $2005,1.63 \%$ in 2010 and $1.38 \%$ in 2013. Further explanation could be focused on high level of corruption that normally induces diversion of the money meant for overhead capital to private uses. While finances earmarked for developmental purpose are high on paper, a very minute part of it is actually spent for the purposes for which they are meant. The same scenario holds for heath expenditure where the results revealed a negative and significant impact on real income. It is worth noting that in spite of the huge expenditure on health posted annually, prevalence and incidence of communicable diseases are still much high in Nigeria. The health sector infrastructures are in a bad state while workers in the sector are not well trained. These factors account for while the rich in the country seek for medical services outside the country and those who cannot afford to travel abroad are left to their fate. Mortality rates (infant, under-five and adult mortality) also continue to be high while average life expectancy has been low over the years. All these could explain why health expenditure showed negative impact on per capita income. Furthermore, incidence of tuberculosis has negative and significant effect on the level of output in Nigeria. This is due to increase in its cases over the years with its attendant effect of reduced labour hour and productivity of the infected persons.

\section{Policy Implications and Limitations of the Study}

Studies on macroeconomic implication of HIV/AIDS are available in most East and Southern African countries. However, this is not the case with Nigeria, where majority of HIV/AIDS related studies are carried out on households. This study therefore, focuses on the macroeconomic effect of HIV/AIDS in Nigeria using data covering the period 1980-2010. The empirical analyses conducted on the data gathered centered on stationarity tests, cointegration investigation and error correction modeling analysis. Overwhelmingly, the findings confirmed a negative and significant relationship between HIV/AIDS and output level in the entire Nigerian economy. This implies that the disease is capable of reducing output level in the country. It is therefore, imperative to curtail the spread of the disease in the country, particularly as the nation seeks to diversify her economy.

It is essential to state however that some limitations are observed in this paper. Firstly, the findings reported in the study are affected by the data point employed. One of the assumptions guiding this data set is that cases of the disease started emerging since 1980. This was the major reason behind the backward projection of HIV incidence data using the UNAIDS Estimation and Projection Package (EPP), Spectrum 4. Additionally, a different methodology may have produced a different result. These limitations notwithstanding, the disease appears to npotend danger for the nation's economy.

\section{References}

Abdulsalam, S. (2010). Macroeconomic effects of HIV/AIDS prevalence and policy in Nigeria: a simulation analysis. Forum for Health Economics \& Policy, 13(2)

Adeoti, A.I. \& Adeoti, J.O (2008).HIV/AIDS and farms' production efficiency in Benue State, Nigeria. African Journal of Biomedical Research, 11, 145 - 153.

Aghion, P. \& Howitt, P. (2007). Capital, innovation, and growth accounting. Oxford Review of Economic Policy, 23(1), 79-93. 
Azuh, D., Osabuohien, E.S.C., Nwaubani, O.O., \& Ugwuanyi, B.E. (2014). Cost implications of the prevalence of HIV/AIDS on the economic development of Nigeria. Journal of Education and Practice, 5(13), 24-34.

Bloom, D. E. \& Mahal, A. S. (1997). Does the AIDS epidemic really threaten economic growth? Journal of Econometrics, 77(1), 105-124.

Bollinger, L., Stover, J. \& Nwaorgu, O. (1999). The economic impact of AIDS in Nigeria. The Futures Group International, Washington, DC.

Bonnel, R. (2000). HIV/AIDS: Does It Increase or Decrease Growth in Africa? ACT Africa World Bank

Centers for Disease Control and Prevention. (2001). HIV/AIDS-United States, 1981-2000. Morbidity and Mortality Weekly Report, 50(21), 430-434

Central Bank of Nigeria. (2010). Statistical Bulletin. Retrieved 7 August, 2012 from http://www.cenbank.org/documents/data.asp.

Central Bank of Nigeria. (2012). Statistical Bulletin. Retrieved 7 August, 2012 from

http://www.cenbank.org/documents/data.asp.

Central Bank of Nigeria, (2014). Statistical bulletin. Retrieved 19 August, 2015 from http://www.cbn.gov.ng/documents/Statbulletin.asp

Chakraborty, S., Papageorgiou, C. \& Perez-Sebastian, F. (2010). Diseases infection dynamics and development. Journal of Monetary Economics, 57 (7), 859-872

Clark, R C. \& Vencatachellum, D. (2003). Economic development and HIV/AIDS prevalence.Cirano Working paper, 2003. Retrieved Feb. 16, 2015, from www.cirano.qc.ca/pdf/publication/2003s-25.pdf.

Cuddington, J. (1993). Modeling the macroeconomic effects of AIDS, with an application to Tanzania. World Bank Economic Review, 7(2), 173-189.

Cuesta, J. A. (2008). Does a Mature AIDS epidemic threaten growth? Inter-American Development Bank, Research Department Working paper series 630' 1300 New York Avenue, N.W. Washington, DC 20577.

Dauda, R.S. (2012). The scourge of HIV/AIDS pandemic and economic performance: the case of Nigeria. Global Journal of Human Social Science, 12(1), 48-64.

Gardner, L. K. \& Lee, S.H. (2010). The impact of HIV/AIDS on health capital and economic growth: a panel study of 38 countries from 1999- 2005. International Journal of Management, 27(1), 153-161.

Hilhorst, T., Liere, M \& Koning, K. (2006). Impact of AIDS on rural livelihoods in Benue State, Nigeria. Journal of Social Aspects of HIV/AIDS, 3(1), 382-393

Iya, I. B., Purokayo, S. G., \& Gabdo, Y. (2012). The effects of HIV/AIDS scourge on production and income among rural households in Adamawa State of Nigeria. Global Journal of Health Science, 4(1), 245-252.

Johansen, S. (1991). Estimation and hypothesis testing of cointegrating vectors in Gaussian vector autoregressive models. Econometrica, 59(6), 1551-1580.

Kambou, G., Devarajan, S. \& Over, M. (1992). The Economic impact of AIDS in an African country:simulations with a General Equilibrium Model of Cameroon. Journal of African Economies, 1(1), 103-130.

Mahal A, Canning D, Odumosu K, \& Okonkwo P (2008) Assessing the economic impact of HIV/AIDS on Nigerian households: a propensity score matching approach. AIDS, 22: Suppl 1S95-101

McDonald, S \& Roberts, J. (2006). AIDS and economic growth: a human capital approach. Journal of Development Economics, 80(1), 228-250.

National Agency for the Control of AIDS, NACA. HIV prevalence rate by states. Retrieved 10 August, 2015 from http://naca.gov.ng/new/content/hiv-prevalence-rate-states.

NACA. (2008). Nigeria UNGASS report. Retrieved 16 August, 2010 from http://data.unaids.org/pub/Report/2008/nigeria_2008_country_progress_report_en.pdf

NACA. (2011). Fact Sheet 2011: Prevention of New Infections in Nigeria. Retrieved from http://naca.gov.ng/content/view/416/lang,en/

NACA. (2012). Global AIDS response progress report (GARPR). Retrieved from http://www.unaids.org/en/dataanalysis/monitoringcountryprogress/progressreports/2012countries/ce_NG_Na rrative_Report[1].pdf 
Dauda, R. S., \& Olaniyan, O. (2017). Macroeconomic Impact of HIV/AIDS in Nigeria: Error Correction Modelling Approach. Advances in Social Sciences Research Journal, 4(4) 31-48

NACA. (2014). Global AIDS response: country progress report on Nigeria. Retrieved 31 July, 2015 from http://www.unaids.org/sites/default/files/country/documents/NGA_narrative_report_2014.pdf

Over, M. (1992). The macroeconomic impact of AIDS in sub-Saharan Africa. World Bank, Washington, D.C PENN World Table. (2012). Retrieved 7 August, 2012 from http://www.econdata.com/databases/imf-and otherinternational/penn-world-table/

Ugwu, D.S. (2009). Socio-economic impact of HIV/AIDS on farm women in Nigeria: evidence from Enugu State. World Applied Sciences Journal, 6 (12), 1617-1624.

UNAIDS. Spectrum/EPP. Retrieved 7 August, 2015 from

http://www.unaids.org/en/dataanalysis/datatools/spectrumepp

UNAIDS (2010).UNAIDS Report on The Global AIDS Epidemic. Retrieved from http://www.unaids.org/documents/20101123_GlobalReport_em.pdf

UNAIDS. (2015a). How AIDS changed everything.Retrieved 27 July, 2015 from http://www.unaids.org/sites/default/files/media_asset/MDG6Report_en.pdf.

UNAIDS and WHO (2009). AIDS epidemic update. Retrieved from http://data.unaids.org/pub/report/2009/jc1700_epi_update_2009_en.pdf

UNAIDS. (2015b). How AIDS changed everything report-HIV estimates with uncertainty bounds. Retrieved 10 August, 2015 from http://www.unaids.org/en/resources/documents/2015/HIV_estimates_with_uncertainty_bounds_1990-2014.

UNGASS (2010). UNGASS Country Progress Report, Nigeria. Retrieved from http://www.unaids.org/en/dataanalysis/monitoringcountryprogress/2010progressreportssubmittedbycountrie s/Nigeria_UNGASS_2010_Final_Country_Report_20110604.pdf

United Nations. (2004). The impact of AIDS. Department of Economic and Social Affairs, Population Division, New York.

World Bank. (1997). Confronting AIDS: public priorities in a global epidemic. New York: Oxford University Press.

World Bank. (2012). World Development Indicators. Retrieved 7 August, 2015 from http://data.worldbank.org/data-catalog/world-development-indicators/wdi-2012

World Bank. (2015). World Development Indicators-Nigeria. Retrieved 7 August, 2015 from http://data.worldbank.org/country/nigeria. 